Original Paper

\title{
Peningkatan Hasil Belajar IPA melalui Model Pembelajaran Problem Based Learning dengan Media Flash Card
}

\author{
Iis Eka Ramadha1, Anggun Zuhaida' \\ ${ }^{1}$ Tadris IPA, IAIN Salatiga, Salatiga, Indonesia.
}

DOI: https:// doi.org/10.29303/jcar.v3i2.834

${ }^{*}$ Corresponding Author:

Anggun Zuhaida, Tadris

IPA, IAIN Salatiga, Salatiga, Indonesia.

Email:

anggunzuh@iainsalatiga.ac.id

\begin{abstract}
Abstrak: Penelitian ini bertujuan untuk mengetahui peningkatan hasil belajar IPA menggunakan model pembelajaran problem based learning dengan media flash card pada materi zat aditif dan adiktif siswa kelas VIII di SMP IT Assalam Bandungan tahun pelajaran 2020/2021. Jenis penelitian ini adalah Penelitian Tindakan Kelas (PTK) yang digunakan untuk memperbaiki proses pembelajaran di dalam kelas. Langkah-langkah PTK, yaitu sebagai berikut: perencanaan (planning), pelaksanaan (action), pengamatan (observing), dan refleksi (reflection) yang dilakukan dalam dua siklus. Subjek dari penelitian ini yaitu kelas VIII B yang berjumlah 24 siswa perempuan. Teknik pengumpulan data menggunakan tes dan observasi. Data yang terkumpul kemudian dianalisis. Peningkatan hasil belajar ini dapat diketahui melalui hasil evaluasi pembelajaran di akhir proses kegiatan pembelajaran. Pada siklus I diperoleh hasil belajar dengan nilai rata-rata kelas sebesar 67,70 dan ketuntasan klasikal sebesar 58\%, 14 siswa dinyatakan tuntas dan 10 siswa dinyatakan tidak tuntas. Sedangkan pada siklus II diperoleh hasil belajar dengan nilai rata-rata kelas sebesar 79,58 dan ketuntasan klasikal sebesar 92\%, 22 siswa dinyatakan tuntas dan 2 siswa dinyatakan tidak tuntas, sehingga dapat disimpulkan bahwa penggunaakan model pembelajaran problem based learning dengan media flash card dapat meningkatkan hasil belajar siswa.
\end{abstract}

Kata kunci: Probelem Based Learning; Media Flash Card; Hasil Belajar.

\section{Pendahuluan}

Pendidikan adalah sebuah kegiatan proses belajar-mengajar untuk memperoleh pengetahuan dan keterampilan. Pendidikan juga merupakan upaya mempersiapakan sumber daya manusia (SDM) penerus bangsa yang cerdas, trampil, berbudi pekerti luhur, dan berkualitas serta mampu menyesuaikan diri dengan perkembangan zaman . Nurkholis (2013) mengemukakan bahwa pendidikan merupakan suatu proses yang diperlukan untuk mendapatkan keseimbangan dan kesempurnaan dalam perkembangan individu maupun masyarakat. Penekanan pendidikan dibanding dengan pengajaran terletak pada pembentukan kesadaran dan kepribadian individu atau masyarakat disamping transfer ilmu dan keahlian. Dengan proses semacam ini suatu bangsa atau negara dapat mewariskan nilai-nilai keagamaan, kebudayaan, pemikiran dan keahlian kepada generasi berikutnya, sehingga mereka betulbetul siap menyongsong masa depan kehidupan bangsa dan negara yang lebih cerah.

Upaya yang dapat dilakukan untuk meningkatkan mutu pendidikan adalah melaui proses pembelajaran yang melibatkan guru dan siswa. Widodo (2013) 
mengemukakan bahwa pembelajaran didesain untuk membelajarkan siswa, artinya siswa ditempatkan sebagai subjek belajar. Dengan kata lain, pembelajaran lebih berorientasi pada aktivitas siswa untuk memperoleh hasil berupa perpaduan antara aspek kognitif, dan psikomotor secara proposional.

Ilmu Pengetahuan Alam (IPA) merupakan salah satu mata pelajaran wajib dijenjang pendidikan sekolah menengah pertama yaitu SMP/MTs sederajat. Widi dan Eka (2019) mengemukakan bahwa IPA merupakan ilmu yang terkonstruksi secara personal dan sosial berlandaskan pendekatan konstruktivisme. Pembelajaran IPA memerlukan kesempatan yang luas bagi peserta didik untuk melakukan inkuiri dan mengonstruksi sains seoptimal mungkin sesuai dengan kapasitas mereka masingmasing dengan memanfaatkan iklim kolaboratif di dalam kelas. Disinilah peran guru sangat vital untuk mengelola proses pembelajaran IPA dengan baik. Peran guru dalam melaksanakan strategi pembelajaran IPA yang baik adalah sebagai sumber belajar, fasilitator, pengelola, demonstrator, pembimbing, motivator, evaluator, dan katalisator dalam pembelajaran, serta pengontrol konsep IPA yang dipahami peserta didik.

Hasil belajar IPA yang dicapai oleh peserta didik di Indonesia yang tergolong rendah dipengaruhi oleh banyak faktor, yaitu karakteristik peserta didik dan keluarga, kemampuan membaca, motivasi belajar, minat dan kosnsep diri, strategi belajar, tingkat kehadiran dan rasa memiliki (Hayat dan Yusuf, 2010). Faktor penghambat lainnya adalah guru masih menggunakan model pembelajaran yang monoton dan hanya mengandalkan pengetahuannya saja, sehingga pembelajaran tampak membosankan. Pembelajaran terkesan tradisional, dengan guru selalu berperan aktif sedangkan siswa cenderung pasif. Akibatnya siswa hanya mengetahui hal-hal yang diterangkan guru tanpa memahami materi dengan mendalam.
Siswa mudah lupa karena mereka cenderung menghafal.

Kesulitan dan kebosanan yang dialami siswa dalam menguasai mata pelajaran IPA merupakan masalah yang perlu diperhatikan guru. Menciptakan kegiatan belajar-mengajar yang mampu mengembangkan hasil belajar siswa yang semaksimal mungkin dan meningkatkan mutu pendidikan adalah tugas dan kewajiban guru (Hutauruk dan Rinci, 2018). Salah satu upaya yang dapat dilakukan guru untuk meningkatkan hasil belajar pada siswa salah satunya yaitu dengan memilih model dan metode pembelajaran yang tepat dan menarik, sehingga peserta didik lebih antusias dalam mengikuti pembelajaran dan dapat meningkatkan hasil belajar.

Model pembelajaran Problem Based Learning (PBL) adalah pembelajaran yang dilakukan melalui pemberian masalah yang berhubungan dengan kehidupan sehari-hari kepada siswa kemudian siswa secara berkelompok mencari alternatif solusi untuk menyelesaikan masalah tersebut. Sedangkan menurut Dutch (dalam Amir 2009) Problem Based Learning merupakan metode instruksional yang menantang siswa agar belajar untuk belajar, bekerja sama dalam kelompok untuk mencari solusi bagi masalah yang nyata masalah ini digunakan untuk mengingatkan rasa keingintahuan serta kemampuan analitis dan inisiatif atas materi pelajaran. $P B L$ mempersiapkan siswa untuk berpikir kritis dan analisis dan untuk mencari dan menggunakan sumber pembelajaran yang sesuai. Menurut Widi dan Eka (2019) Peran guru dalam $P B L$ adalah mengajukan masalah, memberikan pertanyaan, dan memfasilitasi untuk penyelidikan dan dialog. Guru harus memberi kesempatan peserta didik menambah kemampuan menemukan dan kecerdasan.

Pemilihan model pembelajaran yang tepat dan penggunaan media sebagai sarana pembelajaran dapat mempermudah dalam memahami materi yang disampaikan oleh guru. Seperti yang dikemukakan oleh Djamarah (2002) dalam proses belajar 
mengajar kehadiran media mempunyai arti yang cukup penting, karena dalam kegiatan tersebut ketidak jelasan bahan yang disampaikan dapat dibantu dengan menghadirkan media sebagai perantara. Kerumitan bahasa yang akan disampaikan kepada peserta didik dapat disederhanakan dengan bantuan media. Salah satu media yang dapat dikolaborasikan dengan model pembelajaran Problem Based Learning yaitu media Flash card.

Nuha (2016) berpendapat bahwa media flash card adalah alat peraga yang terbuat dari koran dan gambar-gambar, kata-kata yang menarik yang berbentuk kartu berukuran besar yang bertujuan agar siswa dapat mudah untuk memahami isi pesan yang terdapat pada gambar dan tulisan tersebut dengan baik. Media pembelajaran ini merupakan media yang dapat membantu peserta didik dalam mengingat dan mempelajarai informasi baru. Penggunaan flash card melatih peserta didik untuk memperluas jangkauan pandangannya, dimana peserta didik dibiasakan melihat beberapa gambar atau kata yang tertulis dalam kartu dalam satu kali pandangan. Serta dapat menumbuhkan motivasi dan persaingan yang sehat antara peserta didik untuk menghafal apa yang dilihatnya. Suasana kelas dapat lebih hidup dan menyenangkan serta mampu mengurangi kejenuhan.

Berdasarkan pemikiran tersebut dapat dipaparkan bagaimana peningkatan hasil belajar IPA melalui model pembelajaran Problem Based Learning (PBL) dengan media Flash card pada materi zat aditif dan adiktif pada siswa kelas VIII di SMP IT Assalam Bandungan tahun pelajaran 2020/2021?

Tujuan dari penelitian ini yaitu untuk mengetahui peningkatan hasil belajar IPA melalui model pembelajaran Problem Based Learning (PBL) dengan media Flash card pada meteri zat aditif dan adiktif siswa kelas VIII di SMP IT Assalam Bandungan tahun pelajaran 2020/2021.

\section{Metode}

Jenis penelitian ini adalah penelitian tindakan kelas (PTK) yaitu suatu pencermatan terhadap kegiatan yang sengaja dimunculkan, dan terjadi di dalam kelas (Arikunto, 210). Penelitian ini dilaksanakan di SMP IT Assalam Bandungan yang berlokasi di Jalan Ambarawa KM 2 Jetis, Kec. Bandungan, Kab. Semarang, Provinsi Jawa Tengah. Waktu pelaksanaan penelitian dimulai pada tanggal 08 Januari 2021 sampai dengan 22 Januari 2021. Subjek penelitian ini adalah kelas VIII B di SMP IT Assalam Bandungan yang jumlah 24 siswa perempuan tahun pelajaran 2020/2021. Sedangkan objek dari penelitian ini adalah model pembelajaran problem based learning denga media flash card untuk meningkatkan hasil belajar IPA pada materi zat aitif dan adiktif.

Penelitian tindakan kelas ini berupa siklus yang terdapat tahapan-tahapan dalam penelelitiannya. Tahapan dalam PTK anatara lain: 1) perencanaan, 2) pelaksanaan, 3) pengamatan, dan 4) refleksi. Jika siklus I hasil belajar belum mencapai indikator keberhasilan maka dilanjutkan ke siklus II. Siklus akan terhenti jika banyak siswa telah mencapai indikator keberhasilan yang telah ditentukan.

Teknik pengumpulan data dalam penelitian ini adalah observasi, tes, dan dokumentasi. Sedangkan instrument penelitian yang digunakan yaitu lembar tes/ soal dan lembar observasi yang terdiri dari lembar pengamatan guru dan lembar pengamatan peserta didik.

Analisi data penelitian ini dilakukan dengan menggunakan pengamatan dan refleksi pada setiap siklusnya serta membandingkan antara hasil nilai setiap siklus tersebut dengan KKM yang telah ditentukan oleh sekolah yaitu 70. Untuk mengetahui Jika nilai siswa masih di bawah KKM, maka dikatakan belum tuntas, dan untuk nilai sama dengan atau lebih dari KKM maka bisa dikatakan tuntas. Analisis ini bertujuan untuk mengetahui hasil belajar yang telah dicapai 
siswa juga untuk memperoleh respon terhadap proses pembelajaran. data hasil belajar siswa pada ranah kognitif diperoleh dari hasil tes tertulis yaitu post test. Sedangkan hasil belajar pada ranah afektif dan psikomotor diperoleh dari lembar observasi (Wijayanti, 2015).

a. Observasi afektif dan psikomotor

1) Nilai hasil belajar afektif setiap peserta didik diperoleh dengan rumus:

$\mathrm{N}=\frac{\mathrm{R}}{\mathrm{SM}} \times 100$

Keterangan:

$\mathrm{N}=$ nilai yang dicari atau diharapkan

$\mathrm{R}=$ Skor mentah yang diperoleh siswa

$\mathrm{SM}=$ skor maksimum

Persentase nilai hasil belajar afektif siswa secara klasikal diperoleh dengan rumus:

$\mathrm{P}=\frac{\sum \text { siswa tuntas }}{\text { Ejumlahsiswa }} \times 100 \%$

2) Nilai hasil belajar psikomotor peserta didik diperoleh dengan rumus:

$\mathrm{N}=\frac{\mathrm{R}}{\mathrm{SM}} \times 100$

Keterangan:

$\mathrm{N}$ = nilai yang dicari atau diharapkan

$\mathrm{R}=$ Skor mentah yang diperoleh siswa

$\mathrm{SM}=$ skor maksimum

Persentase nilai hasil belajar psikomotor siswa secara klasikal diperoleh dengan rumus:

$\mathrm{P}=\frac{\sum \text { siswa tuntas }}{\text { Ejumlah siswa }} \times 100 \%$

b. Hasil Belajar Kognitif

Ketuntasan belajar secara keseluruhan dapat dihitung dengan rumus sebagai berikut:

1) Penilaian Rata-Rata

Penilaian rata-rata digunakan untuk mengukur prestasi belajar siswa dengan menggunakan rumus sebagai berikut:

$\bar{x}=\frac{\sum x}{\sum N}$
Keterangan:

$\bar{x}=$ Rata-rata hasil belajar siswa

$\sum \mathrm{x}=$ Jumlah semua nilai siswa

$\sum \mathrm{N}=$ Jumlah siswa

2) Ketuntasan Belajar Klasikal

Rumus yang digunakan adalah:

$\%=\frac{f t}{\Sigma f} \times 100 \%$

Keterangan :

$\%=$ presentase ketuntasan klasikal

$\mathrm{ft}=$ frekuensi siswa yang tuntas KKM

$\sum \mathrm{f}=$ jumlah frekuensi seluruhnya (Aqib, 2011).

Indikator keberhasilan penelitian ini menggunakan kriteria ketuntasan individu yaitu siswa bisa mendapatkan nilai melebihi KKM yang telah ditetapkan oleh sekolah $\geq 70$ pada mata pelajaran IPA. Sedangkan untuk kriteria ketuntasan klasikal yaitu siklus akan berhenti apabila 85\% dari total siswa dalam satu kelas mendapatkan nilai ulangan harian $\geq$ nilai KKM (Purwanto, 2009).

\section{Hasil dan Pembahasan}

Model pembelajaran Problem Based Learning merupakan pembelajaran yang penyampaiannya dilakukan dengan cara menyajikan suatu permasalahan, mengajukan pertanyaan-pertanyaan, memfasilitasi penyelidikan, dan membuka dialog. Pembelajaran ini tidak hanya mengharapkan peserta didik untuk mendengarkan, mencatat, kemudian menghafal materi pelajaran, tetapi peserta didik dituntut aktif berfikir, berkomunikasi, mencari dan mengolah data, dan yang terakhir menyimpulkan hasil informasi yang diperoleh. Penggunaan masalah kehidupan nyata sebagai sesuatu yang harus dipelajari siswa untuk melatih dan meningkatkan keterampilan berfikir kritis sekaligus pemecahan masalah, serta mendapatkan pengetahuan kosep-konsep penting (Ridwan, 2014).

Selain itu, peneliti juga mengkolaborasikan model pembelajaran 
Problem Based learning dengan media flash card. Menurut Nuha (2010) media flash card adalah alat peraga yang terbuat dari koran dan gambar-gambar, kata-kata yang menarik yang berbentuk kartu berukuran besar yang bertujuan agar siswa dapat mudah untuk memahami isi pesan yang terdapat pada gambar dan tulisan tersebut dengan baik.

Berdasarkan penelitian yang telah dilakukan, proses pembelajaran menggunakan model problem based learning (PBL) dengan media flash card dapat meningkatkan hasil belajar dan antusias peserta didik. Keaktifan peserta didik mulai meningkat selama proses pembelajaran baik dalam melakukan tanya jawab, membentuk kelompok, melaksanakan penyelidikan memecahkan masalah, berdiskusi kelompok, mempresentasikan hasil penyelidikan di depan kelas, dan mengerjakan soal evaluasi. Sedangkan media flash card digunakan peserta didik untuk membantu proses penyelidikan terhadap tugas kelompok yang diberikan oleh guru selama proses pembelajaran berlangsung.

\section{Tabel 1 Peningkatan Persentase Hasil Belajar Peserta Didik}

\begin{tabular}{llllll}
\hline \multirow{2}{*}{ No } & \multirow{2}{*}{ Siklus } & \multirow{2}{*}{ Rata-rata Kelas } & \multirow{2}{*}{ Persentase Ketuntasan } & \multicolumn{2}{l}{ Ketuntasan } \\
\cline { 5 - 6 } & & & & Tuntas & Tidak Tuntas \\
\hline 1 & Siklus I & 67,70 & $58 \%$ & 14 & 10 \\
2 & Siklus II & 79,58 & $92 \%$ & 22 & 2 \\
\hline
\end{tabular}

Dari tabel 1 dapat dilihat bahwa pada siklus I persentase ketuntasan secara klasikal belum mencapai $\leq 85 \%$ dari jumlah peserta didik, sedangkan pada siklus II persentase meningkat dan telah memenuhi kriteria ketuntasan secara klasikal.

Tabel 2 Persentase Penilaian Afektif dan Psikomotor

\begin{tabular}{llllll}
\hline \multirow{2}{*}{ Aspek yang dinilai } & \multirow{2}{*}{ Kategori } & Siklus I & \multicolumn{3}{l}{ Siklus II } \\
\cline { 3 - 5 } & & Jumlah Siswa & Persentase & Jumlah siswa & Persentase \\
\hline Afektif & Sangat Baik & 10 & $48 \%$ & 20 & $83 \%$ \\
\multirow{3}{*}{ Psikomotor } & Baik & 14 & $52 \%$ & 4 & $17 \%$ \\
& Sangat Trampil & 4 & $17 \%$ & 17 & $70 \%$ \\
& Trampil & 11 & $46 \%$ & 7 & $30 \%$ \\
& Cukup & 9 & $37 \%$ & 0 & 0 \\
\hline
\end{tabular}

Dilihat dari tabel 2 persentase penilaian afektif dan psikomotor mengalami peningkatan dari siklus I ke siklus II selama proses pembelajaran berlangsung.

Peningkatan hasil belajar diiringi dengan meningkatnya aktivitas belajar siswa baik dari aspek kognitif, afrektif, dan psikomotor. Selain itu peningkatan hasil belajar juga ditunjang dengan keberhasilan aktivitas guru selama proses pembelajaran dengan memberi motivasi dan menyiapkan segala hal sebelum pembelajaran dimulai. Berdasarkan hasil penelitian yang telah dilakukan dapat dikatakan penelitian ini sudah memenuhi indikator keberhasilan yang telah ditetapkan yaitu $\mathrm{KKM} \geq 70$ pada mata pelajaran IPA dan ketuntasan klasikal sebesar $85 \%$ dari seluruh peserta didik kelas VIII B pada siklus II, maka penelitian ini dikatakan berhasil dan siklus dihentikan.

\section{Kesimpulan}

Berdasarkan hasil penelitian dan analisis data yang telah dilakukan, dapat disimpulkan bahwa model pembelajaran Problem Based Learning dengan media Flash Card dapat meningkatkan hasil belajar IPA materi zat aditif dan adiktif siswa kelas VIII B di SMP IT Assalam Bandungan tahun pelajaran 
2020/2021. Tahap siklus I diperoleh hasil belajar peserta didik dengan nilai rata-rata kelas sebesar 67,70 dan ketuntasan klasikal sebesar 58\%, 14 siswa dinyatakan tuntas dan 10 siswa dinyatakan tidak tuntas. Sedangkan tahap siklus II diperoleh hasil belajar peserta didik dengan nilai rata-rata kelas sebesar 79,58 dan ketuntasan klasikal sebesar 92\%, 22 siswa dinyatakan tuntas dan 2 siswa dinyatakan tidak tuntas. Peningkatan hasil belajar dari siklus I ke siklus II sebesar 11,88 dan persentase ketuntasan 34\%. Penelitian ini dapat dikatakan sudah memenuhi indikator keberhasilan yang telah ditetapkan yaitu KKM $\geq 70$ dan ketuntasan klasikal yang diperoleh lebih dari $85 \%$ dari seluruh peserta didik kelas VIII B pada siklus II, maka penelitian ini dikatakan berhasil dan siklus dihentikan. Peningkatan hasil belajar juga didukung dengan antusias peserta didik selama proses pemebelajaran, dimana penilaian afektif dan psikomotor yang meningkat dari siklus I ke siklus II.

\section{Saran}

Berdasarkan penelitian yang telah dilakukan maka peneliti menyarankan: (1) Bagi pihak sekolah, terutama kepala sekolah hendaknya selalu meninjau dan memantau proses pembelajaran di dalam maupun luar kelas, serta memberikan pembinaan tentang kreativitas guru dalam mengajar dengan menggunakan model pembelajaran yang interaktif sehingga dapat meningkatkan kualitas peserta didik; (2) Bagi guru, hendaknya guru meningkatkan profesionalisme dalam mengajar dengan menggunakan model, metode, dan media yang kreatif, inovatif, dan efisien yang sesuai dengan kurikulum yang berlaku sehingga menjadikan peserta didik lebih aktif dan antusias dalam proses pembelajaran; (3) Bagi siswa, hendaknya siswa lebih percaya diri dan memperhatikan dengan seksama penjelasan yang disampaikan oleh guru dalam kegiatan pembelajaran; (4) Bagi penulis, penelitian tindakan dengan model problem based learning hendaknya digunakan sebagai acuan untuk melakukan penelitian selanjutnya atau mengembangkan lagi sehingga kualitas pembelajaran dapat meningkat.

\section{Daftar Pustaka}

Amir, T. (2009). Inovasi Pendidikan Melalui Probelem Based Learning. Jakarta: Kencana Prenada Media Group

Aqib, Z. (2010). Penelitian Tindakan Kelas Untuk SD, SLB dan TK. Bandung: CV Yrama Widyas

Arikunto, S. (2010). Prosedur Penelitian Suatu Tindakan Praktik. Jakarta: Rineka Cipta

Djamarah, S.B. (2002). Strategi Belajar Mengajar. Jakarta: Rineka Cipta

Hayat, B., dan Yusuf, S. (2010). Mutu Pendidikan. Jakarta: Bumi Aksara

Hutauruk, P., dan Rinci, S. (2018). Meningkatkan Hasil Belajar Siswa dengan Alat Peraga pada Mata Pelajar IPA Kelas IV SD Nomor 14 Simbolon Purba. SEJ (School Education Journal), 8 (2)

Nuha, U. (2016). Ragam Metedologi dan Media pembelajaran Bahasa Arab Yogjakarta: Diva press

Nurkholis. (2013). Pendidikan dalam Upaya Memajukan Teknologi. Jurnal Kependidikan,1 (1).

Purwanto. (2009). Evaluasi Hasil Belajar. Surakarta: Pustaka Belajar

Ridwan, S.A. (2014). Inovasi Pembelajaran. Jakarta: PT Bumi Aksara

Widi, A.W., dan Eka, S. (2019). Metodologi Pembelajaran IPA. Jakarta: PT Bumi Aksara.

Widodo, L.W. (2013). Peningkatan Aktivitas Belajar dan Hasil Belajar Siswa dengan Metode Problem Based Learning pada Siswa Kelas VII A MTs Negeri Domomulyo Kulon Progo Tahun Pelajaran 2012/2013. Jurnal Fisika Indonesia, 17 (49) 
Wijayanti, Y.A. (2015). Meningkatkan Aktivitas dan Hasil Beljar siswa Kelas VIII D SMP Negeri 1 SeyenganTahun Ajaran 2013/2014 dengan Menggunakan Model Cooperatife Learning Tipe Think-Pair-Share pada Pokok Bahsan Sistem Peredaran Darah Manusia. Skripsi. Yogyakarta:

Universitas Sanata Dharma 